\title{
PROCESS PATENTS FOR COMPUTER PROGRAMS
}

In today's expanding age of scientific and technological advances, the electronic computer ${ }^{1}$ has captured both the imagination and spirit of the times. Its usefulness in the newly developed areas of science, together with its growing applicability to the diverse functions of modern society, reflects its importance and permanence. ${ }^{2}$ Yet the computer's advent has not been without growing pains. In the area of patent law, a continuing controversy has developed over the statutory protection available to the controlling element of the computer-the computer program.

This Comment will discuss the scope and effectiveness of the protection which the patent laws afford to computer programs. Part I will be devoted to a study and description of the computer device and the computer program. Part II will discuss the possibility of patent protection for programs. In this area, three approaches to program patenting will be considered: machine claims, machine combination claims, and process claims. Finally, part III will briefly analyze section 106 of the proposed patent reform bill.

I

THE COMPUTER: MACHINE AND PROGRAM

Since the computer's inception in the early 1950 's, computer research and development has proved one of the largest, fastest growing industries in the world. ${ }^{3}$ Computers have found extensive use in such diversified areas as busmess data processing (including compilation of actuarial tables), commercial banking, communications, education, government activities, process and production control, retailing, and legal research. ${ }^{4}$

Within the computer industry there are three major fronts of emphasis. The first involves the production and merchandising of the computer device. A second sector of the industry is devoted to the development of the peripheral equipment which supplements the main computer mecha-

1 The electronic computer may be classified into two categories-the digital conputer and the analog computer. The digital computer is a logic device, with stored information capabilities, controlled by a program. The analog computer is an unprogramed device which operates by converting physical parameters into equivalent electrical parameters.

2 See W. Desmonde, Compruters and Their Uses (1964); Macdonald, Over 500 Areas of Application of Computers, Computers and Automation, June 1964, at 140; H.R. REP. No. 858, 88th Cong., ist Sess. 81-121 (1963).

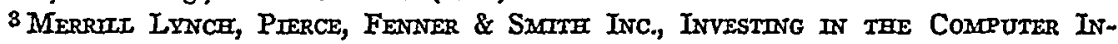
DUSTRY 2 (1967).

4 H.R. Rep. No. 858, 88th Cong., 1st Sess. 107-10 (1963); Merrut. LyNCH, supra note 3, at 2-5; Macdonald, supra note 2, at 140; Proceedings of Special Commiltee on Electronic Data Retrieval, MODERN Uṥ'S OF LoGIC IN LAW 128-40 (1965). 
nism. Both the main computer and its peripheral devices make up what the industry refers to as computer "hardware."

The third division of the industry embraces "software." The software market, which mcludes programing, system analysis, service bureau operations, programing schools, and training centers, is probably as large in dollar value as the hardware portion of the industry. The size of the software industry reflects the importance of computer programs and of programing techniques in the computer industry. Program development may often require a considerable expenditure of time and inoney. These facts have led to the suggestion that software producers utilize the patent laws to protect the investment which a completed program represents. ${ }^{6}$ Those companies dealing primarily in hardware are probably relatively uninterested in such protection. Their initial concern is merchandising their equipment, while the software aspect is provided mainly as a service to their customers.

On the other hand, patent protection would provide a real benefit to those companies dealing exclusively in software and to individual inventors developing new programs or programing methods. It is indeed arguable that the fruits of such labor, the developed program, should be within the sanctuary which the patent laws provide. ${ }^{7}$ Failure to provide adequate protection through the patent system could restrict scientific development and disclosure of programs by these companies and individuals. $^{8}$

5 MerRtic Lynch, supra note 3, at 13. See H.R. ReP. No. 858, 88th Cong., 1st Sess. 103 (1963).

${ }^{6}$ See Eltgroth, Software and the Patent Law, 1966 Patenr Law Annoal 1; Jacobs, Commissioner's Report (re: Computer Programs), 49 J. PAT. OfF. Soc'y 372 (1967); Katona, Legal Protection of Computer Programs, 47 J. Par. OFF. Soc'y 955 (1965); Comment, Software, Statutes and Stare Decisis, 13 How. L.J. 420 (1967); Comment, The Patentability of Computer Programs, 38 N.Y.U.L. Rev. 891 (1963); Note, Patents: Proposed Guidelines to Examination of Programs, 4 TuLsa L.J. 258 (1967). But see Galbi, The Unpatentability of Computer Programs, 1967 Patenr Law Annoal 147; Wessel, Legal Protection of Computer Programs, HaRv. Bus. Rev., March-April 1965, at 97.

7 See sources cited note 6 supra.

8 The Supreme Court, in Sinclair and Carroll Co., Inc. v. Interchemical Corp., 325 U.S. 327, 330-31, 1945, stated that: "The primary purpose of our patent system is not reward of the individual but the advancement of the arts and sciences. Its inducement is directed to disclosure of advances in knowledge which will be beneficial to society; it is not a certificate of merit, but an incentive to disclosure."

The purpose of the patent system itself is to encourage scientific advancement and disclosure by rewarding inventors with limited inonopolies, in the form of seventeen-year patents, on their inventions. The large computer inanufacturers will naturally continue to work in the programing field to support the sale of their devices, whether patent protection is offered or not. However, the potential software company, or the individual, is less likely to risk the time and money required to develop programs where there are no assurances that the end product will ever be protected from use by others. At the very least, scientific disclosure will be stifled as walls of secrecy form in this area. But see STudy No. 15 by 


\section{A. The Computer}

The failure to define clearly and meaningfully the terms "computer" and "computer program" has tended to cloud the issues involved in the controversy over the patentability of programs. A brief description of the computer may help to eliminate some of this confusion.

The computer is an arrangement of electrical switching devices to perform basic arithmetic functions, and magnetic cores to serve as memory storage devices. These are interrelated by a maze of electronic components. The switching devices and magnetic cores make up the computer's arithmetic and memory units, respectively. To supplement these two basic units, a means of input and output is necessary. The input unit serves as an instrument for imparting necessary information to the computer. The output device provides a means by which results are made available. Finally, a control device is necessary to interrelate the various operations of these four units. These five basic units-arithmetic, memory, input, output, and control-make up the computer proper. Thus, the computer initially accepts information by means of the input unit. The memory unit then stores the information presented, with the control unit regulating the storage arrangement. The arithmetic unit then either manipulates or interprets the stored information, these processes involving either actual mathematical calculations or logical comparisons. In either case the control unit determines the way in which the arithmetic unit analyzes the stored information. Finally, the output device gives forth the results which the arithmetic unit produces. ${ }^{9}$

The suggestion that the computer, as a combination of these basic units, is merely " $a$ 'warehouse' of unrelated parts," indicates a surprising misunderstanding of the device. The computer is a complex and intricately designed system of electronic circuitry. Construction of the individual units is accomplished with specific purposes in mind. The interrelation of the basic units likewise reflects the attempt to implement the general purpose of the overall system. Thus the computer, whether of the general or special purpose variety, ${ }^{11}$ is specifically desigued and constructed to perform various tasks.

Subcomar. on Patents for Comar. on the Judictary, 85th Cong., 2d Sess., Machlup, An Economic Review of the Patent System (Comm. Print 1958).

9 See H. Torng, Introduction to the Logicat Design of Switching Circuits 2-3 (1964).

10 Guidelines to Examination of Programs, 829 O.G. PAT. OFF. 1, 2 (1966) [hereinafter cited as Guidelines].

11 Special purpose computers are systems designed for restricted use in particular problem areas-for instance, the handling of a telephone switching system. General purpose computers are designed flexibly to perform a wide variety of functions. In either case, however, the machine is constructed and designed to perform within the range of its uses. 
Keeping these facts in mind, a computer may be described as a prearranged electronic system, with memory capabilities, which operates on stored data according to a stored series of instructions. Only its initial physical construction limits the extent or variety of operations which the computer is capable of performing.

\section{B. The Computer Program}

Within the computer system, the program plays a twofold role. First, it is the velicle which initially conveys data to the input unit. Second, it provides the control unit with the instructions necessary to interrelate the various units of the computer. Together, the data and the instructions form the total information which the program will contain. The scope of the data and instructions, though machine capabilities limit them to some degree, is usually quite broad. This accounts for the computer's wide use in various phases of modern hife.

Pliysically, the computer program is a collection of punched cards. ${ }^{12}$ Eacl card contains either an individual instruction or an element of datum. The totality of data and instructions of the individual cards forms the program proper and represents the information which will be fed to the input unit.

The programer initially writes the program in a computer language composed of standardized words of instruction, and standardized methods of describing mathematical functions. ${ }^{13}$ The program is punched out on the individual cards, which are collectively referred to as the source deck. These instructions are not yet intelligible to the machine itself, which functions according to a basic machine language. ${ }^{14}$ An intermediate step is therefore necessary to translate the source deck into the machine language. This intermediate process is performed by the compiler, which produces a second card deck, written in machine language, known as the object deck. The translated information is then recorded, or stored, on magnetic tapes.

The overall process may be summarized as follows: First, it is necessary to write out a program in a standardized computer language; next, the program is punched onto cards, forming a source deck; the source deck is then fed into the computer's input unit; finally, the compiler, part

12 For the benefit of those not versed in computer technology, this discussion will consider only the punched card program. However, this Comment applies equally to the more sophisticated mediums-such as tapes, discs, and drums-used to impart information to the computer.

13 Common examples of computer programing languages are FORTRAN, ALGOL, and COBOL.

14 The machine language originally built into the computer comprises the basic mathematical and logical procedures by which the device will function. 
of the input unit, translates the source deck into a machine language on a separate card deck-the object deck. The inemory unit then takes the information in the object deck and stores it either on inagnetic tapes or electronically in the magnetic cores.

The above constitutes a basic description of the physical properties of the program device. To explain fully the program and its functions, however, it is necessary also to characterize the mathematical and intellectual concepts which the program represents. A program may vary according to the type of information it contains and the methods by which the machine is to utilize that infonnation. The factors which account for these variances are the "intellectual components" of the computer program, and nay be classified as follows: (1) The mathematical or logical rule or rules which serve as the basis for the program; (2) the "correlation scheme"- the method or system by which rules are used to accomphish the desired result; and (3) the means by which such ideas and information are communicated to the machine, so as to control its operation.

The following example should illustrate the differences between the three intellectual components. In recent years the major television networks have used progranied computers in conjunction with nationwide political elections to predict election results as the returns come in. This method of predicting results involves the use of probability theory and statistical analysis to correlate various chosen factors with the incoming votes to project predictions. For instance, in a presidential election, the networks might take factors relating to state population, electoral votes, and the results in major cities into account. The principles of statistical analysis and probability theory would indicate the percentage and types of votes necessary to make a valid prediction. These principles would also serve to develop the inethod for correlating the votes with the election factors.

The program used to impleinent such a scheme on a computer would be composed of the three described intellectual components. The first component is the mathematical or logical basis of the program-in this case, the principles of probability and statistical analysis.

The second component, the correlation scheme, is the method by which the machine uses the principles of the first component to produce particular results. The correlation scheme in the example is the method by which the principles of probabitity theory and statistical analysis are used in conjunction with particular data to predict results in political elections. Part of the scheine encompasses choosing relevant data and the inethods by which the program will correlate this data with the election returns. 
Finally, the third component is the means for translating the correlation scheme into a form the computer can read-for example, a fortran writeup. This phase encompasses what is usually referred to as programing techniques.

It will be necessary to keep in mind these concepts and definitions, since they are important to the discussion of the patent protection available to programs. The following discussion argues for the proposition that only the second intellectual component of the progran, the correlation scheme, represents subject matter which is patentable under the existing statutes.

II

\section{PATENT CLAIMS AND PROGRAMS}

Congressional authority to issue patents emanates from the Constitution, which gives Congress the power " $[t]$ o promote the progress of science and the useful arts by securing for a limited time to ... inventors the exclusive right to their . . . discoveries." 115 The Patent Act of 1790 contained the initial statutory authority, ${ }^{16}$ with subsequent general revisions occurring in $1836,{ }^{17} 1870,{ }^{18}$ and $1952 .{ }^{18}$

Patent coverage is available where an invention embodies patentable subject matter which is novel, useful, and unobvious. ${ }^{20} \mathrm{~A}$ seventeen-year exclusionary right is available to any invention fulfilling these prerequisites. $^{21}$ During these years the inventor has "the right to exclude others from making, using, or selling the invention." ${ }^{\prime 22}$ At the end of the period the invention becomes available to anyone wishing to make, use or sell it. $^{23}$

15 U.S. Const. art. I, \& 8.

10 Act of April 10, 1790, ch. 7, 1 Stat. 109.

17 Act of July $4,1836, \mathrm{ch} .357,5$ Stat. 117.

18 Act of July 8, 1870, ch. 230, 16 Stat. 198.

19 Patent Act, 35 U.S.C. $\$ \$ 1-293$ (1964). For an excellent account of patent law history, together with a description and interpretation of the changes enacted by the 1952 revision, see Federico, Commentary on the New Patent Act, 35 U.S.C.A. 1-70 (1954).

20 "Whoever invents or discovers any new and useful process, machine, manufacture, or composition of matter, or any new and useful improvement thereof, may obtain a patent therefor, subject to the conditions and requirements of this title." 35 U.S.C. \& 101 (1964) (emphasis added).

"A patent may not be obtained though the invention is not identically disclosed or described ... if the differences hetween the subject matter sought to be patented and the prior art are such that the subject matter as a whole would have been obvious at the time the invention was made to a person having ordinary skill in the art to which said subject matter pertains. Patentability shall not be negatived by the manner in which the invention was made." 35 U.S.C. $\$ 103$ (1964) (emphasis added).

21 See 35 U.S.C. $\$ 154$ (1964).

2235 U.S.C. $\$ 154$ (1964). The same terms are used to describe patent infringement in 35 U.S.C. $\$ 271$ (a) (1964).

23 See 35 U.S.C. $\$ \S 154,271$ (1964). 
As yet the courts have not finally determined the computer program's status within this patent system. The Patent Office has maintained the position that programs by themselves are not patentable, and have rejected all attempts to patent them. ${ }^{24}$

The Patent Office has sought to add some clarity to the problems which the program patentability question engenders by issuing a set of proposed Guidelines which it would use in examining programs. ${ }^{26}$ However, at the public hearing on the proposed Guidelines ${ }^{26}$ attending speakers disagreed as to whether the Guidelines would authorize the Office to issue patents on computer programs. All of the speakers at that hearing opposed the Guidelines, ${ }^{27}$ and the Patent Office has as yet issued no permanent Guidelines. ${ }^{28}$

There is thus a controversy surrounding the program's status within the patent structure. This problem might be most easily understood and resolved by referring to the application of the patent statutes as the case law interprets them. The statutes themselves suggest three forms in which patent protection might be available: machme claims, combination claims, and process claims. ${ }^{29}$ The following discussion will consider the possible uses of these three types of claims $^{30}$ as ways of obtaining program patents.

\section{A. Machine and Combination Claims}

Section 101 of the Patent Act refers to machine inventions as patentable subject matter. ${ }^{31}$ An early case defined the term "machine" to in-

24 ABA, Sumarary of Proceedings, Section of Patent, Trademark and Copyriget LAw 80 (1967) [hereinafter cited as ABA Sumarary]; RuporT of trie President's CoMrmisston on the Patent System, To Promote the Prggress of ... Useful Arts 13 (1966) [hereinafter cited as Patent Report]; Richards, Recent Developments, 3 Patent Law Developments 209, 245-48 (1965).

25 Guidelines, supra note 10. These Guidelines are not an analysis of judicial holdings, but are rather a "tentative theoretical analysis of statulory law." Id. at 1.

26 Hearing on the Commissioner's proposed Guidelines to Examination of Programs, U.S. Patent Office, Washington, D.C., Oct. 4, 1966, BuLc. or the NEW YorK PATENT LAW Assoc., Nov. 1966.

27 See id.; Galbi, supra note 8, at 151.

28 Galbi, supra note 8, at $147,153$.

2935 U.S.C. \& 101 (1964), quoted in note 20 supra.

3035 U.S.C. \& 112 (1964) provides that "a writtel description of the invention and of the manner and process of making and using it" must be given in the application for the patent. The section further provides that "one or more claims particularly pointing out and distinctly claiming the subject matter which the apphicant regards as his invention" must be included (emphasis added). The claims define the boundaries of the patent and fix the amount of protection allowed. See 37 C.F.R. \$\$ 1.71-1.81 (1967); O'Reilly v. Morse, 56 U.S. (15 How.) 62, 118 (1853). Usually the patent will contain several claims of a sequentially diminishing scope, each claim being progressively more specific as to the invention.

3135 U.S.C. \& 101 (1964), quoted in note 20 supra. 
clude "every mechanical device or conibination of mechanical powers and devices to perform some function and produce a certain effect or result."32 Although a principle or node of operation may serve as its basis, a machine is a concrete thing, and not a principle or idea. ${ }^{33}$ As indicated, the machine claim must fulfill the requirements of novelty, unobviousness, and usefulness. ${ }^{34}$ Once obtained, the machine patent protection extends, not only to the machine's precise form, but also to other forms embodying the same invention.$^{35}$ This rule, referred to as the doctrine of equivalents, states that two devices are equivalent if they do the same work in substantially the same way and accomphish substantially the same result, even though they differ in forn, scope, or proportion. ${ }^{36}$

Inventors may also claim as patentable subject matter "combinations of ... devices, ${ }^{\prime 37}$ provided that they neet the statutory requirements. ${ }^{38}$ All of the elements of the combination need not be new, provided that the old elements take on some new functions or qualities as a result of the combination. ${ }^{39}$ Thus a new patentable combination may consist of previously patented or unpatentable machines, and yet produce a new force or effect from that which its separate parts give. ${ }^{40}$

It is possible that a claimant might seek a program patent using a machine or machine combination claim.11 There are several ways of utilizing such an approach. The claimant could seek a patent for the progran itself as a machine. An alternative scheme would be to clain the combination which the union of the program with a computer creates. A

\footnotetext{
32 Corning v. Burden, 56 U.S. (15 How.) 252, 267 (1853).

33 Burr v. Duryee, 68 U.S. (1 Wall.) 531, 570 (1863).

3435 U.S.C. $\$ \S 101,103$ (1964), quoted in note 20 supra.

35 Winans v. Denmead, 56 U.S. (15 How.) 330, 341 (1853).

36 Graver Mfg. Co. v. Linde Co., 339 U.S. 605, 608-09 (1950); Westinghouse v. Boyden Power Brake Co., 170 U.S. 537, 556 (1898).

37 Corning v. Burden, 56 U.S. (15 How.) 252, 267 (1853); see Cantrell v. Wallick, 117 U.S. 689, 694 (1886); Parks v. Booth, 102 U.S. 96, 102 (1880); Reckendorfer v. Faber, 92 U.S. 347,355 (1876). See 35 U.S.C. \& 112 (1964), quoted in note 50 infra, which refers to a "claim for a combination."

3835 U.S.C. \$ 103 (1964); see Lincoln Co. v. Steward-Warner Corp., 303 U.S. 545 (1938); Continental Connector Corp. v. Houston Fearless Corp., 140 U.S.P.Q. 112 (S.D. Cal. 1963), aff'd, 350 F.2d 183 (9th Cir. 1965); National Slug Rejectors v. A.B.T. Mfg. Corp., 164 F.2d 333 (7th Cir. 1947); Niles Tool-Works v. Betts Mach. Co., 27 F. 301 (C.C.D. Del. 1886).

38 E.g., Cantrell v. Wallick, 117 U.S. 689, 694 (1886); Parks v. Booth, 102 U.S. 96, 102 (1880); Reckendorfer v. Faber, 92 U.S. 347, 357 (1876); Continental Connector Corp. v. Houston Fearless Corp., 140 U.S.P.Q. 112 (S.D. Cal. 1963), aff'd, 350 F.2d 183 (9th Cir. 1965).

40 See Niles Tool-Works v. Betts Mach. Co., 27 F. 301, 305 (C.C.D. Del. 1886) (setting down four types of combination patents).

41 Guidelines supra note 10, at 1 . The Guidelines seem to suggest that such an attempt night be allowed.
} 
variation of both approaches would be to base the patent claim on the new use of an old machine, on the theory that the implementation of a new program creates new uses for the "old machine"-the unprogramed computer.

\section{The Program Device}

A claim for a machine patent could refer to the computer program itself as the machine. The claim would refer to the program device-the card deck or magnetic tape-as the object to be patented as a machine. The rationale of such a claim is that the program acts as an actual control device, functioning to control the computer physically.

The trouble with this approach is that the novelty of such a device hes solely in the idea of using cards with punched holes to control the computer. Thus the punched card itself, when initially devised, was a patentable apparatus. ${ }^{42}$ The novelty is not in the contents of the program device-that is, the meaning derived from the positions of the punched holes on the cards. The information on the punched cards cannot affect the patentability of the program as an apparatus. ${ }^{43}$ The Printed Matter cases $^{44}$ bring this point out clearly, indicating that merely reducing an idea to writing or printed form does not amount to an invention. This latter point arises from the principle that ideas or mental processes do not form subject matter patentable under the statute. ${ }^{45}$ Only by showing a physical relationship between the printed matter: and the material structure which effects a new and physical result does a claimant show patentability. ${ }^{46}$

42 I.B.M. Corp. v. United States, 298 U.S. 131, 134, 136 (1936).

43 An analogous situation was presented in Keuffel \& Esser Co. v. Pickett \& Eckel Inc., 85 F. Supp. 855 (N.D. III. 1949), aff'd, 182 F.2d 581 (7th Cir. 1950). The courts involved held that no patentable invention was presented unerely by the integration of new and different scales on a slide rule. Since both the apparatus (the slide rule) and the means of commumication (the use of scales) were old, the sole novelty lay in the meanings ascribed to the scales, which were unpatentable.

44 Ex parte des Granges, 142 U.S.P.Q. 41 (Pat. Off. Bd. App. 1962) (decompression time computer unpatentable where sole novelty resided in the special meaning given printed scales); Ex parte Stange, 124 U.S.P.Q. 238 (Pat. Off. Bd. App. 1960); Ex parte Gwinn, 112 U.S.P.Q. 439 (Pat. Off. Bd. App. 1955) (dice game unpatentable where sole novelty resided in the meanings ascribed to the indices on the dice) ; Ex parte Read, 123 U.S.P.Q. 446 (Pat. Off. Bd. App. 1943) (aircraft rate of speed indicator not patentable where novelty lics solely in the indicator scales and their meaning); Boggs v. Robertson, 13 U.S.P.Q. 214 (D.C. Sup. Ct. 1931) (the use of geometric curves on a map to indicate particular ideas unpatentable, being merely the reduction of an idea to writing). But see Note, The Patentability of Printed Matter: Critique and Proposal, 18 Gro. Wasr. L. REv. 475 (1950).

45 See text acconpanying notes 87-93 infra.

48 Sec Ex parte Dere, 118 U.S.P.Q. 541 (Pat. Off. Bd. App. 1958) ; Ex parte Ehnes, 107 U.S.P.Q. 282 (Pat. Off. Bd. App. 1955). The Dere claim recited a method of scaling off paper according to Englisls and netric measurements, allowing perforations to be made 


\section{Combinations, Equivalency, and the Means-Plus-Function Claim}

(a) Combinations.-As a second approach the patent seeker could claim as the patentable invention the machine combination ${ }^{47}$ of a computer operating in conjunction with a program. ${ }^{48}$ This combination would then be the object of the patent claim. The argument for such a claim is that each new and different program, when combined with a computer, causes the latter to assume new and different electronic states and configurations. From this it follows that if the combination causes the computer to function in a new manner to produce new and unobvious results, it should be patentable.

Applying the statutory requirement of novelty and unobviousness to the computer case will serve to illustrate that the programed machine cannot be patented as a new combination of devices. The computer itself is a totally desigued mechanism. The computer manufacturer has constructed the device with painstaking care, so as to relate properly the individual units and elements with one another. Engineers have specifically designed the operations of each unit into the device. Finally, the manufacturer has built into the computer the capacity to respond to a control program. This being so, it is impossible to produce new or different combination functions merely by changing the instructions on the programs. The most that such changes could do would be to vary the steps involved in the series of internal computer operations. The basic machine functions would remain the same, as they inust if the machine is to operate properly. ${ }^{48}$

(b) Equivalency.-Proponents of program patents have suggested that machine or combination patents which include broad means-plus-

according to the binder to be used. This relation between the physical paper and the structurally related indicia gave a useful and unobvious result and was therefore patentable.

4735 U.S.C. $\S 101$ (1964), quoted in note 20 supra. See cases cited note 37 supra.

48 The following discussion refers to new combinations of internal computer devices created by the computer's interrelation with a program. The coinbination claim could also apply to the union of the computer and the program device. But since the combination of program and computer is an obvious application, it fails to meet the statutory requirements for combination claims. Any novelty which may appear in the combination must refer to the meaning which the program instructions contain. These instructions fall under the principles recited in the Printed Matter cases, or, if claimed properly, the process cases. They cannot, however, give validity to an otherwise obvious combination.

49 This discussion applies solely to instances where a programed computer alone is claimed as a combination. Where the programed computer is merely an element of a combimation it may well fall under patent protection. This is true because the elements of any combination need not be patentable in themselves. Thus a program, developed specifically to control a computer which is an element of a combination, may be effectively protected, since the program presumably would be useless unless used in the patented combination. Note however, that neither the program nor the programed computer have been patented; they are merely protected by the overall combination patent. 
function claims might protect computer programs. ${ }^{50}$ In such cases they have further suggested that the patent be disclosed ${ }^{51}$ in terms of a fixed wire, special purpose circuit ${ }^{52}$ which performs the same function as the computer program to be protected.

To appreciate the significance of these suggestions it is necessary first to define some basic patent law principles. The patent statutes grant to inventors obtaining patents a seventeen-year monopoly on their mventions. ${ }^{63}$ Particular patent statutes which impose penalties on persons who infringe the patented invention protect these monopolies. ${ }^{54}$ Infringement occurs when one "uses or sells any patented invention"t55 or its equivalent. ${ }^{56}$

To be equivalents, two machines must perform the same functions by substantially the same means and accomplish substantially the same result, even though the machines are different in form or shape. ${ }^{57}$ The purpose of the doctrine is to protect the patent by preventing others from making simple changes in the patented machines-for example using a cam instead of a lever, or rearranging the constituent mechanisms-and thereby securing separate patents. Thus, to copy the principle or mode of operation embodied in an apparatus is an infringement, even though the copy is different in form or proportion. ${ }^{68}$

The means-plus-function method of claim drawing also serves to protect patented inventions. It allows the patentee to express elements in

50 "An element in a claim for a combination may be expressed as a means or step for performing a specified function without the recital of structure, materials, or acts in support thereof, and such claim shall be construed to cover the corresponding structure, material, or acts described in the specification and equivalents thereof." 35 U.S.C. \& 112 (1964) (emphasis added).

51 "The specification shall contain a written description of the invention, and of the manner ... of making and using it . . . and shall set forth the best mode . . o of carrying out [the] invention." The specifications must also include claims particularly pointing out the subject matter of the claimed invention. 35 U.S.C. $\$ 112$ (1964).

$62 \mathrm{~A}$ fixed wire system refers to a physical circuit, constructed to perform a special function by the use of electronic equipment (switching circuits, logic devices, etc.). The fixed wire systen is structurally limited to the performance of its designed function. However, this systen may be translated in terms of its logical or electronic functions. Thus, the functional steps involved (which are usually phrased in terms of Boolean logic) can be easily incorporated into a computer program. This may then be used in conjunction with a computer to obtain the same results.

5335 U.S.C. \& 154 (1964).

5435 U.S.C. $\$ \S 281-93$ (1964),

6535 U.S.C. \& 271 (1964).

56 See Smith v. Snow, 294 U.S. 1 (1935); Continental Paper Bag Co. v. Eastern Paper Bag Co., 210 U.S. 405 (1908); Machine Co. v. Murphy, 97 U.S. 120 (1878); Burr v. Duryee, 68 U.S. (1 Wall.) 531 (1864); Winans v. Denmead, 56 U.S. (15 How.) 330 (1853); Denning Wire \& Fence Co. v. American Steel \& Wire Co., 169 F. 793 (8th Cir. 1909).

57 See cases cited note 56 supra.

$58 I d$. 
combination claims generally "as means . . . for performing a specified function." ${ }^{269}$ The purpose of the means-plus-function claim is to allow the patentee the fullest possible degree of patent protection from equivalents. ${ }^{60}$

A scheme to protect a computer program by drafting a broad meansplus-function claim, disclosed in terms of a fixed wire system, would progress as follows. The inventor, to protect a program, designs a fixed wire circuit that performs the same functions as would a computer operating according to this program. ${ }^{61}$ He then obtains a patent, describing his device in broad means-plus-function terms which describe the operation both of the fixed wire system and the programed computer. ${ }^{62}$ The patent, however, describes only the fixed wire circuit to avoid a rejection on the grounds that computer programs are not patentable.

At this point, the patentee can argue that a computer, programed to function in the same manner as his patented fixed wire circuit, is an equivalent device. Therefore, no one may use the program, which the patentee originally sought to protect, without imfringing the patent on the fixed wire circuit. By using this scheme, then, the patentee is able to protect and monopohze the use of his computer program.

5935 U.S.C. \& 112 (1964).

60 See Smith v. Snow, 294 U.S. 1 (1935); Continental Paper Bag Co. v. Eastern Paper Bag Co., 210 U.S. 405 (1908); Royal Typewriter Co. v. Remington Rand, 76 F. Supp. 220 (D. Conn. 1947), aff'd, 168 F.2d 691 (2nd Cir. 1948). However, the claims cannot be drawn so broadly as to encompass general fields. See General Electric Co. v. Wabash Appliance Corp., 304 U.S. 364, 370 (1938) (claim for filament for electric light made up of tungsten grains "of such size and contour" as to prevent sagging was rejected); O'Reilly v. Morse, 56 U.S. (15 How.) 62 (1853) (claim reciting method for generating symbols, without regard to means, by use of electric currents, rejected). But see In re Smellie, 1940 Dec. Com. Pat. 514 (exception may lie in this area if the invention represents a revolutionary step in a pioneering field).

61 For example, the program could be designed to give the information (directional coordinates and angle of elevation) necessary to aim a canon at a moving target (where the position and velocity of the target can be determined-as by radar). A computer functioning according to the program would solve for the necessary information by plugging the position and velocity parameters into predetermined differential equations. In other words, the computer would provide an answer by making mathematical operations.

The same process could be accomplished by a fixed wire circuit-using analog equipment-set up to operate according to the relevant equations. In other words electromic equipment could actually be set up and connected in such a way as to give the necessary information to aim the gun. However, setting up such a system with physical devices could be troublesome, time consuming, and expensive-especially when one could easily write up a program to perform the same task.

62 For instance, the claim might describe one element of the apparatus as "a means for determining the angle of elevation of the canon." The "means" used in the program case would be a mathematical formula. The "means" used in the case of the fixed wire circuit would be an actual combimation of electronic devices (which are set up to solve the particular mathematical formula). However, the means-plus-function claim, being plrased in such a broad manner, would apply to both cases. 
The problem with this argument is that where a device introduces a new mechanical principle or mode of operation enabling it to perform the same or similar functions in a substantially different way than another patented device, no infringement action will lie. This is true even though the new machine may fall within the literal wording of the patented machine's claim. ${ }^{63}$ Therefore, where the second machine performs the same function as a first, but by substantially different means, it is, for patent law purposes, a different device.

The fixed wire circuit and the programed computer operate in substantially different manners. Confusion arises because the principles or logical methods involved in describing a fixed wire circuit or an allegedly equivalent programed computer can be the same. However, the mode of operations, or means, which the two devices employ to implement the original principle are substantially different. The fixed wire circuit relies on a specific mterrelation of electronic equipment to effect the desired result. There will usually be quite a difference in the types of individual components which the fixed wire circuit will use as compared with those which the programed computer will employ. ${ }^{64}$ Nor will the programed computer utilize the same interrelation of physical units which make up the novel fixed wire circuit. The fact that the latter device operates on a stored program further indicates the fundamental differences underlying the two devices. The two systems simply rely on different modes of operation, and though rendering similar results, function in substantially different manners. As a result, they are not equivalents.

With regard to the means-plus-function method of claim drawing, it applies only to the particular elements of the claim, and cannot cover the entire claim. ${ }^{65}$ The claim may describe all the elements of a combination,

63 See Graver Mfg. Co. v. Linde Co., 339 U.S. 605 (1950); Westinghouse v. Boyden Power Brake Co., 170 U.S. 537 (1898); Winans v. Denmead, 56 U.S. (15 How.) 330 (1853); Stearns v. Tinker \& Rasor, 252 F.2d 589 (9th Cir. 1957).

64 Thus, a fixed circuit machine may employ electronic circuit devices to perform functions of addition, integration, etc. Such units would have to be specifically and permanently interrelated to one another in order to perform the function desired. This logical interrelation would have to take into account electrical considerations. Smoothing circuits, balancing systems, output units, etc. might be integrated into the system as well. On the other hand, there would be no such permanent interrelation of units in an equivalent programed computer. Since the conputer is based on a binary systen, the means for performing individual functions (addition, integration, etc.) will be different. Finally, the function parts of a computer are basically interrelated in a manner quite distinct from the fixed wire circuit. By its very nature the digital computer is conceived with different considerations in mind (e.g., program control).

65 See Application of Fuetterer, 319 F.2d 259 (C.C.P.A. 1963); Stearns v. Tinker \& Rasor, 252 F.2d 589 (9th Cir. 1957) ; Ex parte Bullock, 1907 Dec. Com. Pat. 93. The socalled "single means" claim is still invalid, even with the passage in 1952 of 35 U.S.C. \& 112. For example, a claim for an airplane could not read as "a ineans for air travel." 
even the single novel element, in means-plus-function terms, if it also particularly and distinctly points out their novel cooperative relationship. ${ }^{66}$ And though the claim need not specifically describe the material and structure, the clainant inust include them in the specifications, so that the courts may construe the claim to cover the description and its equivalents. ${ }^{67}$ Thus a patented fixed wire circuit with a claim reciting means-plus-function terms will still have specifications disclosing the device to a recognizable degree. Since the novel cooperative relationship of a fixed wire circuit does not apply to a programed computer, the latter will not be an equivalent, even where the claimant uses the means-plusfunction approach. ${ }^{68}$

Finally, the patent system allows applicants to use the means-plusfunction claim to ensure that the patent protection will fairly cover the claimed invention. This allows the claim to recite distinct elements in such terins as reasonably to encompass equivalent devices. In each case, the means-plus-function must apply only to a distinct and different unit. In a programed computer, however, the means described in each case must necessarily refer to and encompass the entire programed mechanism. This is so because the programed computer functions as a single interrelated umit, and not as a combination of distinct elements.

\section{Nerw Use of Old Machine}

As a final argument one might claim that the use of each new program creates a new use for an "old machine"-the unprogramed computer. The "new use" doctrine usually applies to cases where the applicant transfers a machine used in one industry to another industry for a new and different use. For instance, a wine manufacturer's use of a cotton gin as a grape crusher might be considered a new use of an old inachine.

${ }^{68}$ See Bryan v. Sid W. Richardson, Inc., 254 F.2d 191 (5th Cir. 1958); Stearns v. Tinker \& Rasor, 252 F.2d 589 (9th Cir. 1957); In re Fuetterer, 319 F.2d 259 (C.C.P.A. 1963). These cases give effect to $\S 112$, allowing the means-plus-function claim. The section was passed in part to overcome the confusion resulting from Halliburton Oil Well Cementing Co. v. Walker, 329 U.S. 1 (1946), which was interpreted to require a full and concise description of elements in a combination claim. See Bryan v. Sid W. Richardson, Inc., supra at 194.

07 37 C.F.R. \& 1.71(b) (1967) requires that the specifications "describe completely a specific embodiment of the process." 35 U.S.C. $\$ 112$ (1964) requires that the claimant "set forth the best mode contemplated . . of carrying out his invention." 35 U.S.C. $\$ 113$ (1964) requires drawings whenever "the nature of the case admits" of it. See discussion in note 30 supra.

68 The means-plus-function claim does not have the same scope as a process claim. It is necessary to limit this type of claim to the patented machine and its legal equivalents. As stated in Del Francia v. Stanthony Corp., 278 F.2d 745, 748 (9th Cir. 1960): "An inventor of an improvement "cannot by mere use of the word "means" appropriate any and all kinds of mechanisms or devices which may perform the specified function ... other . . than that which is described in the patent or ... its mechanical equivalent. ...'" 
The discussion of this "new use" doctrine in relation to programed computers will touch briefly on two points. First, it is not possible to claim as a machine patent the new use of an old machine, no matter how novel or inventive the use might be. ${ }^{69}$ The statute ${ }^{70}$ merely allows the patenting, as a process claim, of the new use of the old machine. ${ }^{71}$ Second, where the new use is analogous to prior applications, it is unpatentable. ${ }^{72}$ For example, the use of a cotton gin to crush grapes might be so analogous as to deny patentability.

The new use of a programed computer will therefore take the form of a process claim, and will be patentable only to the extent that the process fulfills the patent requirements. This particular problem will be the topic of the following section. Usually there will be no novelty in the idea of employing a programed computer in new fields. Since the computer is inherently designed to perform a wide range of functions, applications of computers in modern society will normally reflect analogous or obvious uses. ${ }^{73}$ Where the process claim's novelty lies in its other aspects, however, it may well be patentable-even though involving the obvious use of a computer.

\section{B. Process Claims}

For reasons that will become clear, the process claim seems to present the only prospects for program patent protection. To be valid a processlike a machine-must be new, useful, and unobvious. However, the process may be patentable even though the machines or means used to carry out the process steps may be neither new nor patentable. ${ }^{74}$

69 See In re Hack, 245 F.2d 246 (C.C.P.A. 1957); In re Ducci, 225 F.2d 683 (C.C.P.A. 1955); Riesenfeld, The New United States Patent Act in the Light of Comparative Law I, 102 U. PENN. L. Rev. 291, 298-300 (1954).

7035 U.S.C. $\S 101$ (1964). The section allows patents on "any new and useful process, machine ... or any new and useful improvement thereof."

71 See note 69 supra.

72 Potts v. Creager, 155 U.S. 597 (1895); B \& M. Corp. v. Koolvent Alum. Awning Corp., 257 F.2d 264 (7th Cir. 1958); In re Ducci, 225, F.2d 683 (C.C.P.A. 1955). See also Riesenfeld, supra note 69, at 298-300. The "new use" doctrine actually goes to the point of obviousness. If the "new use" is so analogous to the prior use that its applicability would have occurred to a person of ordinary skill, then it is obvious and unpatentable. The more remote the fields involved are, the less obvious will the application be, until the point of "new use" is reached.

73 The diverse uses of a programed computer to solve mathematical problems, administer bank accounts, or control chemical reactions are not unobvious when compared with each other. Novelty in each particular case will turn, rather, on the program method employed.

74 E.g., Expanded Metal C9. v, Bradford, 214 U.S. 369 (1909); Cochrane v. Deener, 94 U.S. 780 (1877), 


\section{Patentable Processes}

One of the earliest attempts to define a patentable process occurred in the Supreme Court's decision in Cochrane v. Deener. ${ }^{75}$ The process to be patented was a method for purifying flour by the use of lot air blasts. In allowing the patent, the Court defined a valid process as

a mode of treatment of certain materials to produce a given result. It is an act, or a series of acts, performed upon the subject-matter to be transformed and reduced to a different state or thing. If new and useful, it is just as patentable as is a piece of machinery. . . . The process requires that certain things should be done with certain substances, and in a certain order; but the tools to be used in doing this may be of secondary consequence. ${ }^{76}$

The opinion indicated that only processes dealing with physical materials would be patentable. However, it seemed to require further that an actual change of state, or transformation, of the subject matter be involved.

The Court was to broaden this initial definition in subsequent cases. In Tilghman v. Proctor ${ }^{77}$ the Court had before it a process for dissolving fat into its constituent elements by mixing it with water under a high degree of pressure and heat. The process in fact involved a physical object, which underwent a change in state. However, the Court in redefining "process" did not limit it to these circumstances. Instead, it broadly stated that a process was simply a mode of acting which produced a useful result. ${ }^{78}$

The Telephone Cases $^{79}$ followed this line of development by extending the process definition to include electrical processes. In question was Bell's process of sound transmittal by electricity. The process was valid because, as the Court indicated, it involved controlling of a force of nature, electricity, to accomplish a particular purpose: sound transmission. $^{80}$ Though lere there were no real changes of the subject matter's physical state, the process still related to physical activities-the modulation of electrical waves.

In Expanded Metal Company v. Bradford ${ }^{81}$ the Court considered a meclianical process for making expanded sheet metal. The Court again extended the process definition-this time to include mechanical transactions-stating that "an invention or discovery of a process or method

\footnotetext{
7594 U.S. 780 (1877).

$76 \mathrm{Id}$. at 788 .

77102 U.S. 707 (1881).

$78 \mathrm{Id}$. at 728 .

79126 U.S. 1 (1888).

$80 \mathrm{Id}$. at 532 .

81214 U.S. 366 (1909).
} 
involving mechanical operations, and producing a new and useful result"82 was patentable.

The Supreme Court's decision in Waxham v. Smith ${ }^{83}$ evidences the result of the process definition's development. The Court broadly stated that a patentable process was one involving "the use of materials in a particular manner [to secure] the performance of [a] function by a means which had never occurred in nature." ${ }^{84} A$ valid process therefore need not involve changes of physical state in the subject matter. ${ }^{85}$ As long as the process embodies physical materials, agents and effects, and produces a novel and useful result, it is patentable. ${ }^{86}$

Comparing the process definition to the program's correlation scheme indicates their sinnilar natures. The correlation scheme is the method of using the principles fornning the program's basis to effect a particular result. In other words, it is a process-an act or series of acts directed toward a particular result. The problem is to determine whether the correlation scheme fulfills the requirements for process patentability.

\section{Mental Processes}

As a corollary to the Court's process definition it is apparent that where the process does not employ and affect plysical elements, but is concerned solely with intangibles, it is not patentable. As a further requirement then, a valid process nuust involve statutory subject mattersubject matter whicll is within the scope and coverage of the Patent Act.

The courts, in interpreting the patent statutes, have distinguished between statutory subject matter and subject matter which, though conforming to the statutory requirements, is nevertheless unpatentable. Included in the latter nonstatutory group are: (1) Mathematical, mental, or logical fornulae, methods, or steps; ${ }^{87}$ (2) discoveries of physical phe-

82 Id. at $385-86$.

83294 U.S. 20 (1935).

84 Id. at 22 .

85 See In re Ernst, 71 F.2d 169 (C.C.P.A. 1934) (though Cochrane implies that a valid process must relate to the treatment of some material, other Supreme Court decisions are not so limited); Ex parte Westcott, 135 U.S.P.Q. 81 (Pat. Off. Bd. App. 1961) (process need not involve physical transformation or change of state, only the application or utilization of some element or power of nature or law of physics to produce a useful result); Ex parte Roth and Rich, 118 U.S.P.Q. 112 (Pat. Off. Bd. App. 1957) (Cochrane is merely a non-exclusive test for a method claim); Ex parte Kharasch, 39 U.S.P.Q. 123 (Pat. Off. Bd. App. 1938); Ex parte Kettering and Sittler, 35 U.S.P.Q. 342 (Pat. Off. Bd. App. 1936) (doctrine of Cochrane extended so that it is no longer essential to a valid process that subject matter be transformed to a different state or thing).

86 See cases cited note 85 supra.

87 Atlantic Works v. Brady, 107 U.S. 192 (1883); Lyman v. Ladd, 232 F. Supp. 754 (D.D.C. 1964), affd, 347 F.2d 482 (D.C. Cir. 1965); Supermold Corp. v. American Tire Mach. Co., 27 F. Supp. 385 (S.D. Cal. 1939), afj'd, 114 F.2d 759 (9th Cir. 1940); In re 
nomena or natural laws; ${ }^{88}$ (3) primted matter; ${ }^{80}$ and (4) ways or methods of doing business. ${ }^{90}$ The reasoning behind such exclusions seems to be as follows: were intangibles such as ideas, mathematical formulae, and natural laws patentable, large segments of knowledge would be withdrawn from public use and subjected to intellectual monopolies. This result would contradict one of the basic policy reasons for granting patents, that of encouraging scientific advancement. ${ }^{.1}$ Practical reasons also weigh agamst allowing patenting such intangibles. Because of the wide dissemination of knowledge and ideas throughout the world, it would be difficult, if not impossible, to determine whether a particular idea, formula, or principle was novel and unobvious. The problems of enforcing such patents against infringement seem also to be overwhelming.

It has been common to refer to processes involving subject matter of the nonstatutory nature as "mental" processes. The name indicates that the subjects claimed under the process-whether mathematical formulae, natural laws, or business methods-involve nothing more than mental or intellectual operations. The term algorithm has also been popularly applied to indicate mental processes. ${ }^{92}$ An algorithm is a statement of a conclusion based on a sequence of steps involving mathematical, logical, mental, or natural rules or principles. Whatever their name, processes involving nonstatutory subject matter are themselves unpatentable. ${ }^{93}$

The test then is to determine if a process describes a series of steps which apply "physical force through physical agents to physical objects"94 and thus produces physical effects directly from the process' implementation. ${ }^{55}$ If so, it is patentable. ${ }^{96}$ As used here, "physical" means

Abrams, 188 F.2d 165 (C.C.P.A. 1951); Application of Shao Wen Yuan, 188 F.2d 377 (C.C.P.A. 1951); In re Cooper, 134 F.2d 630 (C.C.P.A. 1943); Ex parte Meinhardt, 1907 Dec. Com. Pat. 237.

88 Mackay Radio and Tel. Co. v. Radio Corp. of America, 306 U.S. 86, 94 (1939); O'Reilly v. Morse, 56 U.S. (15 How.) 62, 112-15, 119 (1853); LeRoy v. Tatham, 55 U.S.

(14 How.) 155, 174 (1852).

89 See Printed Matter cases cited in note 44 supra.

${ }^{90}$ Conover v. Coe, 99 F.2d 377 (D.C. Cir. 1938); Hotel Security Checking Co. v. Lorraine Co., 160 F. 467 (2d Cir. 1908).

B1 See note 8 supra.

02 See Guidelines, supra note 10 , at 1.

93 See cases cited note 97 infra. But see Jessup, Patentability of Mental Processes, 40 J. Par. OFr. Soc'y 482 (1958); Note, The Patentability of Mental Processes, 15 MicH. L. REV. 660 (1916).

${ }^{94}$ Application of Shao Wen Yuan, 188 F.2d 377, 381 (C.C.P.A. 1951).

05 See Johnson v. Duquesne Light Co., 29 F.2d 784, 786 (W.D. Pa. 1928); Ex parte Meinhardt, 1907 Dec. Com. Pat. 237, 238.

${ }^{96}$ See In re Cox, 342 F.2d 1017 (C.C.P.A. 1965) (method of filtering extraneous signals from electronic waves reflected from subsurface materials by adding a theoretically determined waveform to augment the correct signal); Crosley Corp. v. Westinghouse Electric and Mfg. Co., 52 F. Supp. 884 (W.D. Pa. 1944) (method of testing refrigerators on a mass 
of or pertaining to natural or material things-for example, chemicals, machines, or electricity —as opposed to things mental, spiritual, moral, or imaginative-for example, ideas, equations, or rules. However, if the process merely describes steps requiring mental operations, which produce no results proceeding directly from the process' operation unless the intelligence of some person is brought into play, it is unpatentable. ${ }^{07}$ The following examples should serve to clarify these definitions.

Tilghman v. Proctor $^{98}$ is a good example of a patentable or physically related process. The process involved was a method for dissolving fat into its constituent elements by mixing it with water under a high degree of pressure and heat. The novelty of this process over prior methods lay in the steps involving the use of water under conditions of high temperature

production basis by creating and observing frost lines and comparing them with a predetermined standard); Ellis v. Coe, 49 U.S.P.Q. 232 (D.D.C. 1941) (method of determining the electrolytic condition of living tissue by applying electrodes and measuring current-use of a force of nature to produce a useful result); Ex parte Tripp, 141 U.S.P.Q. 918 (Pat. Off. Bd. App. 1963) (method of thermal compensation for machine tools, involving manipulative steps to derive signals and insert motions); Ex partc Ehnes, 107 U.S.P.Q. 282 (Pat. Off. Bd. App. 1954) (method of arranging discrete index cards to create a structural relationship which, when photographed, produced a new sheet of information); Ex parte Monroe, 105 U.S.P.Q. 376 (Pat. Off. Bd. App. 1955) (method of controlling the mixing of fluids by using the relation existing between the pressure of fluid flow and the ratio of fluid constituents to regulate the flow and rate of addition of constituents); Ex parte Baymiller and Vose, 68 U.S.P.Q. 403 (Pat. Off. Bd. App. 1945) (method for designing, by use of mathematical models, and manufacturing golf clubs).

${ }^{97}$ See Lyman v. Ladd, 232 F. Supp. 754 (D.D.C. 1964), afj'd, 347 F.2d 482 (D.C. Cir. 1965) (method for balancing automotive wheel suspension elements based on mathematical apportionment); Halliburton Oil Well Cementing Co. v. Walker, 146 F.2d 817 (9th Cir. 1944), aff'd mem., 326 U.S. 696, rev'd on other grounds, 329 U.S. 1 (1946) (method for determining and locating unknown obstructions in cil wells by obtaining and computing values); In re Heritage, 150 F.2d 554 (C.C.P.A. 1945) (method for determining optimum application of coating for porous surface based on the use of the senses to make selections according to a predetermined system); Don Lee, Inc. v. Walker, 61 F.2d 58 (9th Cir. 1932) (method for counterbalancing engine shafts according to mathematical determinations); In re Cooper, 134 F.2d 630 (C.C.P.A. 1943) (method for making special steel based on mathematical determination of carbon content needed); In re Bolongaro, 62 F.2d 1059 (C.C.P.A. 1933) (method of producing printed publications from manuscripts, based on mathematical apportionment); Ex parte Masten, 150 U.S.P.Q. 473 (Pat. Off. Bd. App. 1966) (system for regulating traffic, based on mathematical equations); Ex parte Jenny, 130 U.S.P.Q. 318 (Pat. Off. Bd. App. 1960) (method for preparing profile map on graph paper based on mathematical equations); Ex parte Hitchins, 99 U.S.P.Q. 288 (Pat. Off. Bd. App. 1953) (system for timing traffic in two directions based on mathematical formulae); Ex parte Toth \& Nutter, 63 U.S.P.Q. 131 (Pat. Off. Bd. App. 1944) (method of determining pump pressure in oil well based on steps of correcting and determining, requiring use of the senses); Ex parte Mayne, 59 U.S.P.Q. 342 (Pat. Off. Bd. App. 1943) (method for combating seasickness by causing victim to concentrate senses of hearing, seeing, and feeling on particular objects); Ex parte Meinhardt, 1907 Dec. Com. Pat. 237 (system for spaclng and apportioning free hand lettering).

98102 U.S. 707 (1880). 
and pressure to produce the desired effects. The result was a more economical and effective way for breaking down fats. The subject matter of the process was statutory-or patentable-since it concerned physical objects (fats and water), physical forces (heat and pressure), and physical results (the breaking down of fats).

In contrast one might consider the process described in Application of Shao Wen Yuan, ${ }^{99}$ which the court rejected as a mental process. The disputed clain recited a method for exactly determining the desired air foil ${ }^{100}$ profile of airplane wings for certain desired aerodynamic characteristics. The process involved a series of steps for "computing" and "determining" values, which a inathematical formula was to "convert" to form the desired air foil curve. ${ }^{101}$ Here the novelty over prior methods lay solely in the use of the specified mathematical equations. All the steps in the process required only mental or intellectual operations. The result of the process was not the air foil itself, but was simply a mathematical model, indicating the curvature which one constructing an air foil would use to attain the desired aerodynamic characteristics.

While these cases may be reasonably clear, maintenance of the mental-physical distinction is not so simple where the process combines both types of steps. This was the situation that In re Abrams ${ }^{102}$ presented. The process in dispute embraced a inethod for petroleum prospecting. The process employed physical steps, which required boring and sealing off of holes and reducing the pressure in the holes. However, to determine whether petrohferous deposits were present, the process required inental steps of "determining" and "ineasuring" rates of pressure rise by means of instruments, and comparing these values by plotting them on a graph. ${ }^{103}$ Since the sole novelty of this inethod of petroleum prospecting was embodied in the inental steps, the court rejected the process claim. In doing so, the court enunciated three rules to be used as guides in similar cases: (1) If all the steps of a process claim are purely mental in character, the subject matter is not patentable; (2) if a process claim embodies both physical steps and mental steps, yet the alleged novelty or advance over prior art resides in one or more of the mental steps, then the claim is unpatentable; and (3) if a process claim embodies both physical steps and mental steps, yet the alleged novelty or advance over prior art resides in physical steps, and the inental steps are incidental parts of the process, the claim is patentable..$^{104}$

99188 F.2d 377 (C.C.P.A. 1951).

100 The airfoil is any surface on an aircraft which is designed to obtain reactions from the air through which it moves.

101188 F.2d at 378.

102188 F.2d 165 (C.C.P.A. 1951).

$103 \mathrm{Id}$.

104 Id. at 166. 
The foregoing examples should indicate the difficulties one will encounter when trying to apply the mental-physical distinction to particular process claims. One cannot answer the patentability question by determining whether, in fact, the claimant has demonstrated a true process. Whether mental or physical, the invention described will be a process-a series of steps directed toward a particular result. The sole question upon which patentability rests is whether the steps which the process employs are inental concepts or pliysical acts. ${ }^{105}$ The courts have been clear about the handling of process claimis once they have made this latter determination. ${ }^{106}$ They have been less specific, however, about the rules or standards for differentiating between a mental and physical step.

Ex parte Lewis and Horner ${ }^{107}$ involved a method of determining the probable productivity of oil sands by analyzing the characteristics of core samples. The alleged novelty of the inethod centered on the discovery of a new relationship between the ratio of free gas to free water in the core samples. By following steps of "determining," "comparing," "dividing," "testing," "recording," "measuring," "converting," and "correlating" obtained values in conjunction with the novel relationship, it was possible to determine the presence of oil in the samples. ${ }^{108}$ The examiner ${ }^{109}$ rejected the claim as being unpatentable over prior art, and as being based on mental processes involving mathematical computation. The Board of Appeals reversed on the grounds that the method, showing a new and novel relationship with respect to material substances, provided a novel solution to a problem in a practical way. The inventive aspect resided not in the mental steps recited but in the novel relationship of physical materials.

When compared with the claim in Abrams it certainly is not immediately obvious how the cases are distinguishable. Both processes concerned methods for oil prospecting, and both recited steps of "measuring," "determining," and "comparing" to accomphish this result. Yet the Lervis process was patentable, while that in Abrams was rejected as a mental process. The only distinction seems to be that in Lervis, the recited steps reflected a novel physical relationship between physical elements. In Abrams, no such novel physical relationship existed.

$105 \mathrm{Id}$. at 167.

108 See, e.g., In re Abrams, 188 F.2d 165 (C.C.P.A. 1951); Application of Shao Wen Yuan, 188 F.2d 377 (C.C.P.A. 1951); Ex parte Tripp, 141 U.S.P.Q. 918 (Pat. Off. Bd. App. 1963).

10748 U.S.P.Q. 141 (Pat. Off. Bd. Off. 1940).

$108 \mathrm{Id}$. at 142.

109 The examiner makes the initial decision as to the patentability of all submitted claims. See 35 U.S.C. §§ 7, 131, 132 (1964). 
Perhaps the best that can be said for the mental-physical step distinction is as follows: (1) Where the process steps employ or involve novel physical effects or relationships of physical objects, they will be patentable; ${ }^{110}$ (2) Where the process steps are detached from, or fail to employ or involve novel physical effects or relationships of physical objects, they are not patentable. ${ }^{111}$ Since the "measuring" and "determining" steps in Lewis employed a novel physical relationship of physical elements-the ratio of free gas to free water-they were patentable, or physical, as the courts seem to prefer.

On the other hand, the "measuring" and "determining" steps in Abrams did not involve a novel physical relationship of objects or effects. Neither the machine from which the required measurements were read nor the relationship between pressure in the bored holes and the rate of pressure rise was novel. ${ }^{112}$ Since the sole novelty lay in the intellectual use of the information obtained-graphing of the information and interpreting the graphs-the whole process was unpatentable.

\section{The Correlation Scheme}

The preceding analysis indicates the difficulty one may encounter in trying to determine the patentability of certain process claims. Cases on either side of the process spectrum may be clearly distinguishable. Where mental and physical steps intermingle, however, the decision as to patentability may be quite difficult. The cases seem to offer no clear standards for distinguishing a mental from a physical step. Due to the nature of the subject matter, it seems doubtful that one can draw any general and meaningful standards. Perhaps the best approach to the problem is the case by case basis, with the mental-physical step question being one of one the courts have apparently taken: to decide each process claim on a fact. ${ }^{113}$

This last point bears directly on the program process claim problem. The Patent Office, having taken the position that programs inust by definition involve only mental steps, has rejected all program oriented process claims. However, the Patent Office should consider the program oriented process - the correlation scheme- on a case by case basis, rather than rejecting it summarily. If the correlation scheme is totally detached from novel physical effects or relationships, then it would not be patentable. If, as in the Leweis case, it is based on and involves a novel physical effect or relationship, it should be patentable.

110 See cases cited note 96 supra.

111 See cases cited note 97 supra.

${ }^{112}$ See In re Abrams, 188 F.2d 165 (C.C.P.A. 1951).

113 Id. at 168. 
For example, suppose that a programed computer performed the process steps in Lewis-those of "determining," "comparing," "testing," and "correlating." There seems to be no valid reason why the process, when described in terms of a programed computer, should be any less patentable than before. It is not the program but the process which the program represents in its correlation scheme which is the subject of the patent.

The Patent Office's reluctance to allow patents on program processes may stem in part from its failure to recognize the different aspects of a computer program. But to be realistic, it must consider any program in light of its three intellectual components: (1) The rule forming the program base; (2) the correlation scheme used to implement the program purpose; and (3) the translation techniques used to transform the program into a machine readable form. Where novelty in a program process is based solely on the first or third aspect, then the patent claim must fail. ${ }^{114}$ The first aspect merely involves mathematical, mental, or logical formulae or rules. For instance, in the Lewis example, the first aspect would be concerned solely with a mathematical ratio between free gas and free water. The third aspect also fails to supply patentable subject matter, since it involves only the mental steps necessary to translate the problems and goals enunciated into a machine readable language. However, the correlation scheme may well be patentable if drawn to proper subject matter.

This discussion should indicate that a process need not be unpatentable merely because it describes steps as being performable by a programed computer. A patentable process should be valid without regard to its means of implementation, be they programed computer, equivalent fixed wire circuit, or otherwise. In any case, the same process is involved.

\section{Two Computer Cases}

Proponents of computer program patents ${ }^{115}$ in argning their position have emphasized two cases in particular-Ex parte Egan, Kister and Scott, ${ }^{116}$ and Ex parte King and Barton. ${ }^{117}$ Ex parte Egan, Kister and Scott involved a method of determining the positions of underground strata. The process involved plotting certain obtained values on two precalculated charts by "plotting" on the first chart one set of values,

114 This is true even though the programed computer can perform valuable services in these areas. Thus a programed computer can solve differential equations or invert matrices which would otherwise be a practical impossibility for a man to perform. Nevertheless, such functions, though extremely beneficial, are based on unpatentable mental processes.

115 See note 6 supra.

116129 U.S.P.Q. 23 (Pat. Off. Bd. App. 1960).

117146 U.S.P.Q. 590 (Pat. Off. Bd. App. 1964). 
"scaling off" or "reading" from that chart a second set of values, and "utilizing" these values on the second chart to obtam the desired information. ${ }^{118}$ The Board of Appeals upleeld the claim, stating that a method in which apparatus-the charts-are used in a particular way to accoinphish a useful result-unskilled personnel doing complex, time consuning work in a novel and simple way-is within the realm of patentable processes. The Board pointed out that the mathematical steps or mental effort involved in making up the charts preceded the actual patentable process and were not to be confused with the physical implementation of the process. ${ }^{119}$ This much of the case seems merely to recognize the principles developed in prior cases. However, the Board analogized the process to a method of operating a computer, comparing the charts employed in the process with a computer. It stated further that "the method of operating apparatus [the program] in operating a computer are distinct from the method of computation." "120 These general statements were made with no attempt to define what was meant by the term "prograin" or "computer." If "the method of operating apparatus" - the prograin-means the program's correlation scheme, then in certain cases it may be distinct froin the "method of computation"- the mathematical or algorithmic basis. Whether it is will depend upon the rules already delineated, as applied to the facts of the particular case. If the term "program" refers to the mathematical or algorithmic premise upon which it is based, then to consider it as being distinct from the "method of computation" and therefore patentable is erroneous.

Furthermore, the novelty of this process claim lay in the use of the charts to determine certain parameters, rather than using complicated and involved mathematics. In other words, the charts, when used together, gave the same result which the complex equation calculations would have given. Since this new method supplied equivalent results by simpler and faster means, through the novel use of charts, it was patentable. This is not to say that the method of calculating by equations was patentable. Nor was the process of transforming mathematical equations to graphical equivalents patentable. ${ }^{121}$ As the court indicates, this all preceded the actual process itself. It was the idea of using charts so constructed in

118129 U.S.P.Q. at 23-24.

119 Id. at 26 .

120 Id.

121 Ex parte Jenny, 130 U.S.P.Q. 318 (Pat. Off. Bd. App. 1961), indicated that the mere translation of a formula into charts or graphs is not patentable, since it is novel only in its mental steps. This case was not mentioned in Egan, so it is difficult to ascertain the degree of influence it may have had on the opinion. It would seem to preclude the possibility that the method claim in Egan was considered as novel and patentable because it involved the translation of the formulae onto the two graphs implemented in the process. 
conjunction with underground strata positioning steps in a simplified and time saving manner which produced a patentable process.

The same novelty does not lie in the idea of transposing mathematical equations to programs and then using them in conjunction with other operations to produce faster results. The computer by definition is designed and constructed to perform tasks more efficiently and in less time than would normally be possible. This characteristic is common to any use which the computer might be applied. Since this is an obvious purpose of any computer, and therefore any computer program, it would fail to meet the unobviousness requirement of section $103,,^{122}$ and would be unpatentable.

The second case commonly cited, Ex parte King and Barton, refers to a machine rather than a process claim. The claimant attempted to obtain a patent on a special purpose computer, programed to process mathematically data stored therein. Performance of the processing was to be according to a mathematical system already known to mathematicians as the Polish Notation. The examiner rejected the claims on the ground that they failed to make any structural distinctions between the claimed computer and any nonprogramed computer. The Board, in dictum, disagreed with much of the examiner's reasoning, but upheld the rejection on the sole ground that the claims "merely set forth the result or function accomplished by any computer operating on data in Polish Notation." 123 Thus, the method merely described "routine operations of storage and processing means normally found in stored program computers."124 The effect of this decision in the area of program process claims seems to be entirely in he with prior cases. The implication is clear that a program correlation scheme which merely recites algorithmic steps based on mathematical premises, such as the Polish Notation system, is unpatentable. This is no more nor less than what has been said before.

\section{Analysis}

Careful study of the computer program's nature and of the cases in the realm of process claims leads to the following conclusions. First, the courts and the Patent Office have failed to define a program clearly and to recognize its distinct aspects. A proper conceptual definition of a program should distinguish between its three intellectual components: The mathematical or algorithmic premise, which is the basis of the program; the correlation scheme, which interrelates the process steps so as

12235 U.S.C. $\$ 103$ (1964), quoted in note 20 supra.

123146 U.S.P.Q. at 591 .

124 Id. 
to perform the program's function; and the techniques involved in transposing the first two aspects to a machine readable form.

Second, a process, to be patentable, must effect immediate physical consequences in physical subject matter. Though generically within the general class of processes, methods which involve only mental steps will not be patentable. Processes combining both mental and physical steps may be patented if the novelty of the method hes in its physical aspects. Determinations as to patentability in this area must depend upon the facts of each particular case.

Third, the case law in this area provides adequate background for the determination of the patentability of processes involving computer programs. It is apparent that if the basis of the alleged novelty lies either in the program's mathematical or algorithmic foundation, or in the techniques of program translation, it will be unpatentable as a mental process.

The correlation scheme, however, may present patentable subject matter. Since it will necessarily appear as a mixture of both physically related steps and mental or algorithmic steps, the patentability of each correlation scheme will depend upon its own peculiar fact situation, as construed in light of the principles governing these cases. Therefore, if an examination of the program indicates that the novelty in the correlation scheme resides solely in the mentally related properties, it will be unpatentable. If, however, the novelty lies in its use of plyysical forces, materials, and relationships, it will be patentable, notwithstanding that a programed computer is capable of implementing some of the steps involved.

Fourth, the rejection of an otherwise patentable process merely because it describes steps associated with a computer program is illogical, and uncalled for in light of case history. Yet sucli is apparently the approach which the Patent Office has adopted. ${ }^{125}$

If such an approacly is maintained, claimants will draft their claims to avoid formal reference to programs, while describing in substance the method embodied therein. ${ }^{126}$ For example, the Patent Office recently issued a process patent relating to the processing of geophysical information for locating oil bearing subsurface formations. ${ }^{127}$ The specifica-

\footnotetext{
125 See note 24 supra.
}

${ }^{128}$ See Comment, The Patentability of Computer Programs, 38 N.Y.U.L. REv. 891 (1963). The author indicates that patent protection may be available where circuitous methods are used to obscure the true nature of the program invention. The Patent Office's proposed Guidelines also seemed to emphasize the form of the disclosure over the substance of the process claim. The mental-physical step distinction, however, should depend not so much on the words of description as on what, in fact, is actually being claimed. Certainly the cases presented have indicated that a study of the words used in defining the process steps will be of limited use in the determination of patentability.

127 Patent No. 3,312,933, issued April 14, 1967. The process involved a method of 
tions ${ }^{128}$ described in terms of patentable analog equipment ${ }^{120}$ a means of carrying out the process. It was obvious that the claimants meant to use a programed digital computer to execute the process. ${ }^{130}$ The patent application itself indicated that it was quite possible to set up a digital computer to perform the process in accordance with the described technique. ${ }^{131}$ Presumably, had the claim actually referred solely to a digital computer, programed to perform the process, rather than the disclosed analog circuit, the Patent Office would have rejected the otherwise patentable process.

Further complications result when such patents, obtained through such circuitous methods, come before the courts in an infringement action. Questions will arise as to whether process claims which disclose circuit or analog equipment to perform the steps will cover the equivalent programed method. If not, and if the program correlation scheme continues to be unpatentable, there will be little protection afforded to a great many of the otherwise valid processes in this area. ${ }^{132}$ On the other hand, to say that a progranr equivalent, though unpatentable itself, infringes a patented process is an equally illogical result. Recognition of the correlation schenie of the computer program as a patentable process will help to alleviate most of these problems. ${ }^{133}$

filtering geophysical data in a manner such that the filter response varied with time. Essentially, the process involved the reinserting of frequencies, attenuated by the earth and the seismic instruments, into a seismogram (an information bearing electronic signal). Since the earth has a frequency response which varies with depth, the seismogram changes in frequency content as a function of time. The invention involved a novel method of reinserting the attenuated frequencies on a time function basis, to compensate for the earth's depth variant filter response.

12835 U.S.C. $\S 112$ (1964), quoted in note 30 supra.

129 Analog devices are electronic components which may perform inathematical or logical functions by relating physical values to electrical parameters. In order to solve a particular problem, these devices must be specifically arranged in a fixed-wire system. Thus, any analog circuit will be able to solve only the particular problem for which it was constructed. See discussion in note 52 supra.

130 It seems highiy unlikely that the claimants would go to the trouble of actually constructing a fixed wire analog circuit setup when the same result could he obtained by sinply programing a computer to execute the process.

131 Patent No. 3,312,933, issued April 14, 1967, at 8.

182 For example, the process patent describing the filtering of geophysical data was disclosed in terms of analog equipment, though apparently meant to be a programed digital computer. However, if the patent does not cover the program method, the process described will be wholly unprotected, since programs will obviously be used to carry out the disclosed claims.

${ }^{133}$ Ex parte Lewin, 154 U.S.P.Q. 487 (Pat. Off. Bd. App. 1966), may indicate a step in this direction. This involved a process claim for a method of retrieving words stored in a content addressed memory according to a tag-bit driving system. The exaniner rejected the claim as being drawn to the inherent function of the disclosed special purpose computer. Such a rejection may be refuted by showing a materially different apparatus capable of performing the same process. The Board of Appeals reversed on the grounds that the process 
III

THE PATENT REFORM BILL

A full discussion of the computer program's status in the patent system requires some mention of the patent reform bills ${ }^{134}$ presently before Congress. The administration's bill, ${ }^{135}$ which seeks far-reaching reforms, is based on the Report of the President's Commission on the Patent System. ${ }^{136}$ In section IV of the report, the Commission recommended the exclusion of computer programs as patentable subject matter, whether claimed as machines, combinations, or processes, ${ }^{137}$ and this proposal is embodied in the administration's bill. ${ }^{138}$ Whether such an exclusion is reasonable or necessary can best be judged by considering the Commission's explanations for its position.

First, the Commission indicated that the uncertainty and confusion as to program patents necessitated a statutory solution for the problem. ${ }^{139}$ But much of the uncertainty and confusion in this area is due to the general failure of those involved to define adequately the subject of concern. For instance, the Commission broadly defined a program as a "series of instructions which control or condition the operation of a data processing machine." ${ }^{140}$ This Comment has attempted to demonstrate that a more meaningful definition would be in terms of the program's intellectual components. Then the case law would be fully adequate to handle the questions related to program patents.

was performable by a programed general purpose computer, which constituted a materially different machine. Ex parte King \& Barton, 146 U.S.P.Q. 590 (Pat. Off. Bd. App. 1964), was distinguished as applying solely to the patentable difference between a special purpose computer and the obvious programing of a known general purpose computer. Thus it could not support the examiner's contention that a materially different apparatus must also be patentably different. This decision impliedly admits that the particular process was equally valid disclosed in either manner-by the special purpose computer or by the programed general purpose machine. This of course recognizes the claim's substance, rather that its form of disclosure. Since the method mvolved fits the definition given the correlation scheme of a program, the case may be read as acknowledging the patentability of this aspect of the program.

134 S. 1691, H.R. 7454, 90th Cong., 1st Sess. (1967) (little change from present systen1); S. 1042, H.R. 5924, 90th Cong., 1st Sess. (1967) (administration bill seeking far reaching reforms); S. 2597, 90th Cong., 1st Sess. (1967) (compromise bill, supported by the ABA).

135 S. 1042, H.R. 5924, 90th Cong., 1st Sess. (1967).

136 PATENT REPORT, supra note 24.

137 Id. at 12-13.

138 "A plan of action or set of operating instructions, in whatever form presented, to cause a controllable data processor or conputer to perform selected operations shall not be patentable." S. 1042, § 106, H.R. 5924, § 105, 90th Cong., 1st Sess. (1967).

139 See Patent Report, supra note 24, at 13. See also ABA Sumcrary, supra note 24 at 80 .

140 See PAtent Report, supra note 24 , at 12 . This definition is similar to the one en1bodied in the administration bill, quoted in note 138 supra. 
Second, the Commission believed that the Patent Office would be unable to examine program patent applications due to its lack of classification technique and requisite search files; also, that reliable searches to determine patentable novelty would not be economical or feasible because of the tremendous volume of prior art. ${ }^{141}$ This contention may be answered by making two points. First, where the patent laws have granted to inventors the right to obtain patents on their inventions, it seems unreasonable to exclude arbitrarily certain inventions merely because they pose some administrative problems for the Patent Office. The particular function of the Patent Office is to issue patents, not avoid them because they involve added work. ${ }^{142}$ Second, if the program patent problem is resolved in the manner suggested by this Comment, the amount of additional work on the Patent Office's part will be minimal. Program related patents will be available only in the small area where the correlation scheme fulfills the necessary process claim requirements. Such patent apphications will appear in the form of process claims, which the Patent Office is fully qualified to handle.

Third, the Commission stated that program growth was satisfactory without patent protection, and that, at any rate, copyright protection for programs was already available. ${ }^{143}$ With regard to the first point, this Comment has indicated that the majority of programs, relating to mathematical or algorithmic functions, will not be patentable. Growth in this area may very well be satisfactory without patent protection. However, this Comment is concerned with the restricted area of the correlation scheme. Failure to grant patent protection here will definitely affect both development and economic interests, as in the case of any process. ${ }^{144}$

The latter contention, concerning copyright protection, also seems dubious. The copyrighting of programs has numerous drawbacks, ${ }^{145}$ a major one being that, while it would prevent copying, it would not protect the use of novel and inventive ideas contained in the program. ${ }^{140}$ One could copy the inventive ideas, incorporate them in a sufficiently different program form, and yet obtain the same results, without infringing the copyright.

141 Patent Report, sutpra note 24 , at 13.

142 See ABA SumorarX, supra note 24 , at 81.

148 Patent Report, supra note 24, at 13.

144 See note 132 supra and the accompanying text.

${ }^{145}$ See Katona, Legal Protection of Compater Programs, 47 J. PaT. OFr. Soc'y 955 (1965); Lawlor, Copyright Aspects of Computer Usage, 11 BuLL. CopyruoHT Soc'y 380 (1964); Comment, Copyright Protection for Computer Programs, 64 CoLus. I. Rev. 1274 (1964).

140 See Baker v. Selden, 101 U.S. 99 (1879); Alfred Bell \& Co. v. Catalda Fine Arts, 191 F.2d 99 (2d Cir. 1951); Muller v. Triborough Bridge Auth., 43 F. Supp. 298 (S.D. N.Y. 1942). 
The foregoing analysis suggests that the exclusion of computer programs which the patent reform bill contemplates is both unnecessary and unreasonable. It is unnecessary because, by using a proper approach, the patent system is fully capable of handling the program patent problem. It is unreasonable to the extent that it will prevent otherwise proper process patents froin issuing solely because they are described in terms of a program's correlation scheme.

Passage of section 106 may also create further problems. It is possible to draft a process claim which can employ either a patentable fixed wire system or a programed computer. Presumably, a patent will issue if the process claim discloses only fixed wire equipment as a means of implementation. A question then arises as to the effect of implementing the same process by means of a programed computer. It seems inconsistent to hold this to be an infrimgement, for the implicit admission im such a holding is that the programed computer is in fact capable of performing a patentable process. On the other hand, failure to do so will nullify the protective effect of the fixed wire process patent. Again, it is possible to avoid these problems by accepting that the correlation scheme of a computer program may well be a patentable process.

\section{CONCLUSION}

The controversy surrounding the protection of computer programs indicates that much of the confusion in this area of the patent law has arisen from a failure to define clearly the subjects of discussion. The computer device itself is a totally designed system preconstructed with the capabilities of performing its designated tasks. Within this system the computer program functions as a control device. A meaningful understanding of the program requires faithful recognition of certain conceptual distinctions. The program embodies three distinct intellectual components: Its mathematical base, the correlation scheme by which it controls plyysical elements, and the programing techniques for translating the first two aspects into machine readable form.

Given these defimitions, the patent statute provides three areas wherein protection might extend to programs: The process claim, the apparatus claim, and the combination claim. The first of these areas, the process claim, provides the only real basis for program protection. Process patents should issue for any patent claim referring to a novel correlation scheme of the program, where its method properly relates to plyysical functions. However, if the sole novelty of the claimed program lies in its mathematical premise, or in its programing techniques, then such method claims should be rejected as representing mental processes. Since the case 
law in this area provides adequate grounds for these decisions, no process claim should be rejected solely because it involves a computer program.

Aside from the process claim, there are no other means of securing program patent protection. The program cannot be considered as a machine itself, since the novelties and differences embodied by any program he merely in its imtellectual components. Since a programed computer is not equivalent to a fixed wire circuit, drawing broad means-plusfunction claims will be equally unavailing for securing protection for the program. Neither does the addition of a program cause the computer to function as a new combination, since the computer already has the inherent capacity to implement any program instruction. The obvious application of the computer to the various areas of society precludes the possibility of patenting the programed device as a new use of an old machine, nnless novelty hes in some other aspect of the new use process claim.

Finally, the exclusion of the computer program from the patent system, as proposed by section 106 of the patent reform bill, is unreasonable and unnecessary. Any problems which the computer program poses can be adequately handled within the present patent framework.

Max W. J. Graham, Jr. 